Studies in Classical Linguistics in Honor of Philip Baldi 


\section{Amsterdam Studies in Classical Philology}

Editorial Board

Albert Rijksbaron

Irene J.F. de Jong

Caroline Kroon

VOLUME 17 


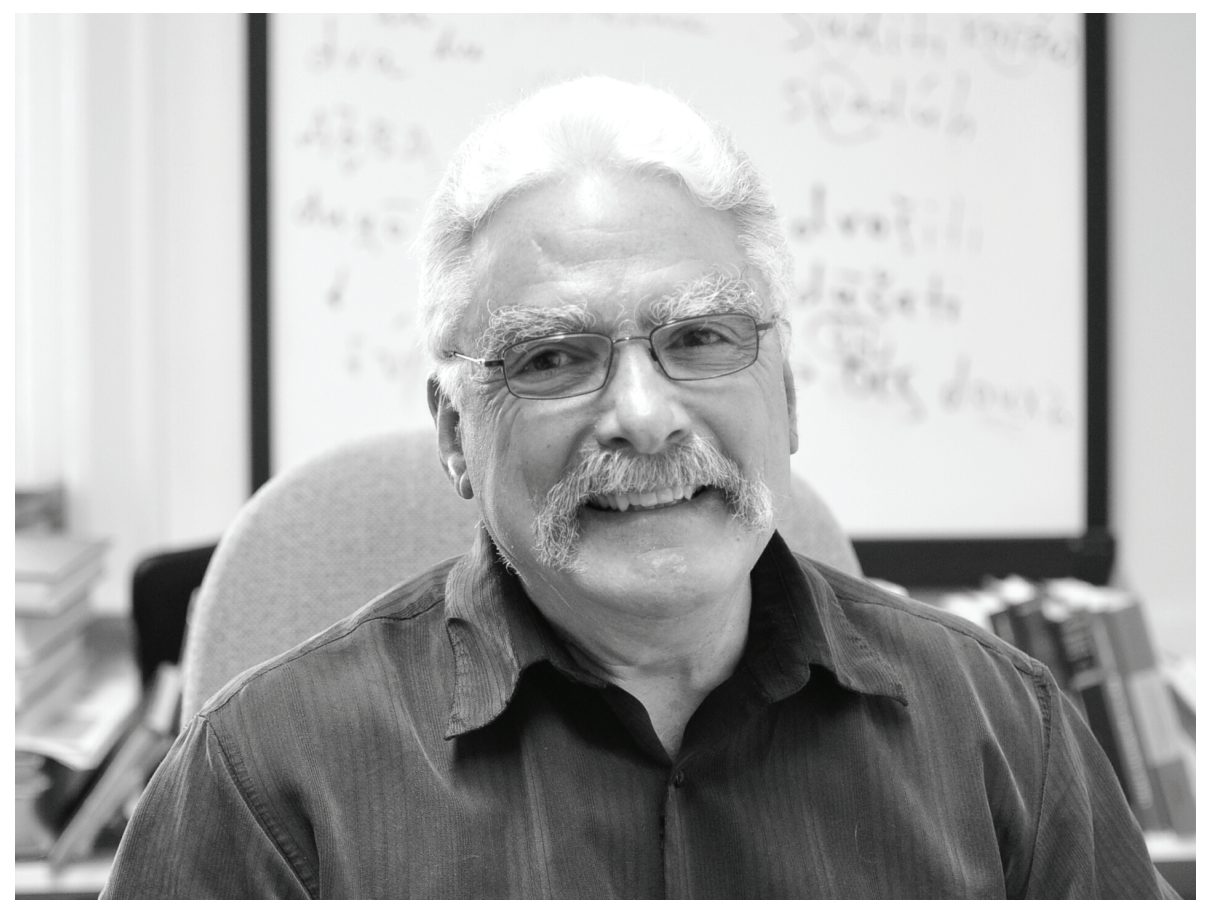




\section{Studies in Classical Linguistics in Honor of Philip Baldi}

Edited by

B. Richard Page and Aaron D. Rubin

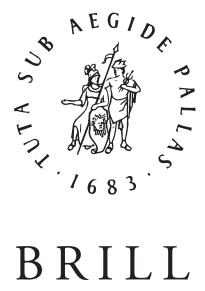


This book is printed on acid-free paper.

\section{Library of Congress Cataloging-in-Publication Data}

Studies in classical linguistics in honor of Philip Baldi / edited by B. Richard Page and Aaron D. Rubin.

$$
\text { p. cm. }
$$

Includes bibliographical references.

ISBN 978-90-04-18866-2 (alk. paper)

1. Linguistics. 2. Language and culture. I. Page, B. Richard. II. Rubin, Aaron D., 1976-

III. Baldi, Philip. IV. Title.

P26.B33S78 2010

$410-\mathrm{dc} 22$

2010030371

ISSN $\quad 1380-6068$

ISBN 9789004188662

Copyright 2010 by Koninklijke Brill NV, Leiden, The Netherlands.

Koninklijke Brill NV incorporates the imprints Brill, Hotei Publishing,

IDC Publishers, Martinus Nijhoff Publishers and VSP.

All rights reserved. No part of this publication may be reproduced, translated, stored in a retrieval system, or transmitted in any form or by any means, electronic, mechanical, photocopying, recording or otherwise, without prior written permission from the publisher.

Authorization to photocopy items for internal or personal use is granted by Koninklijke Brill NV provided that the appropriate fees are paid directly to The Copyright Clearance Center, 222 Rosewood Drive, Suite 910, Danvers, MA 01923, USA.

Fees are subject to change. 


\section{CONTENTS}

Tabula Gratulatoria $\ldots \ldots \ldots \ldots \ldots \ldots \ldots \ldots \ldots \ldots \ldots \ldots \ldots \ldots \ldots$ VII

Editor's Preface ....................................... IX

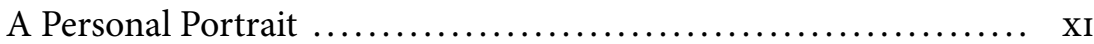

Pierluigi Cuzzolin

The Professional History and Publications of Philip Baldi (through

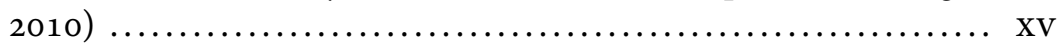
Aaron D. Rubin

1. A Few Words for Springs in Aeschylus ..................... 1 Daniel W. Berman

2. How to Move Towards Somebody in Plautus' Comedies: Some Remarks on the Adverb obuiam ........................... 7 Pierluigi Cuzzolin

3. Baltic Palaeocomparativism and the Idea that Lithuanian is a Neo-Latin Language Pietro U. Dini

4. Blight and Bugs: The Semantics of Latin Plant Diseases and the Perils of Latin Translations of the OT book of Psalms.......... 31 Paul B. Harvey, Jr.

5. On Latin (s)tritavus .................................. 43 Brian D. Joseph

6. On Complex Syllable Onsets in Latin Christian Lehmann

7. Having Something that You Don't Own: Apud Possessive Constructions in Latin and a Comparison with Locative Possessive Sentences in Irish Andrea Nuti

8. Gender Assignment of Latin Loanwords in Early Germanic:

A Case Study of Latin vinum 75

B. Richard Page 
9. The Use of quia and quoniam in Cicero, Seneca, and Tertullian... 81 Harm Pinkster

10. Dum loquimur, fugerit inuida aetas: On Tense and Actionality of Latin verba dicendi................................ 97 Hannah Rosén

11. Thoughts on the Origin of the Latin and Indo-European Nominal Declension William R. Schmalstieg

12. Latin aliās 'at another time' Brent Vine

13. Etruscan mlak [ and the Interpretation of the Inscription on the Santa Teresa kyathos ................................... 141 Rex Wallace

14. Poetry in Motion: The Semantic Transformation of poetria in the Middle Ages........................................ 149 Stephen Wheeler

Index of Authors Cited 165 


\title{
THE USE OF QUIA AND QUONIAM \\ IN CICERO, SENECA, AND TERTULLIAN
}

\author{
Harm Pinkster \\ olim Universiteit van Amsterdam
}

\section{Introduction}

In Early and Classical Latin there was a clear semantic distinction between the causal subordinators quoniam 'since' on the one hand and quia and quod 'because' on the other. Whereas quoniam clauses contain the speaker's (or writer's) personal ('subjective') point of view in support of what is stated in the superordinate clause, often referring to shared knowledge, quia and quod signal an 'objective' cause / effect relationship between the contents of the subordinate and superordinate clauses. The traditional French equivalents are puisque for quoniam and parce que for the other two. Common English translations are since (also as) and because. ${ }^{1}$ The former functions in so-called disjunct clauses, the latter two in in so-called adjuncts (Pinkster 1990: 36). The semantic difference is reflected in the distribution of the words. Quoniam is at home in argumentative texts, for example no less than 129 instances of quoniam in Lucretius' didactic poetry (only 104 of quia). On the other hand there are very few instances of quoniam in Livy's narrative, and most of them in orations (39 out of 46) (Pinkster 2009: 314).

Szantyr (1965: 627) states that 'Bei Dichtern seit Lucr[etius], namentlich aber in der silbernen Latinität wird quoniam ganz synonym von quia und quod (nicht selten in Wechsel mit diesen Konjunktionen, z. B. bei Colum[ella] ... u.a.)', which is confirmed, according to Szantyr (1965: 627-628), by its co-occurrence with corresponding expressions like ideo 'therefore' in the superordinate clause. On closer inspection there is little support for the latter statement in the authors on the BTL (Bibliotheca Teubneriana Latina) cd-rom (see Pinkster 2009). In addition to my earlier publication I mention as a continuous point of difference

\footnotetext{
${ }^{1}$ For the differences between quoniam, and quia, quod see Bolkestein (1991), Fugier (1989), Mellet (1994, 1995).
} 
between quoniam and quia the absence of quoniam clauses in answer to the idiomatic question quid ita? 'how come?'. Quia is quite normal in this context (Plautus 12 times out of 24, Terence 2/13, Cicero 11/26, Rhet. Her. 6/6). There are also a few purpose clauses with $u t$ in answer to quid ita? (For quod clauses see below). ${ }^{2}$ Alongside distributional differences like the one just mentioned an analysis of the contexts in which quia and quoniam are used by Columella shows that Szantyr's statement about this author is incorrect. The two subordinators each have their own meaning, which, of course, does not mean that there are no contexts in which both are possible. A speaker / writer is to some extent free to present a reason as 'subjective' or 'objective.' Typical contexts for quoniam in Columella are shown in (1)-(3) below. A typical context of quia is shown in (4). The two subordinators are definitely not 'ganz synonym' (details in Pinkster 2009).

(1) Quoniam de bubus satis praecepimus, opportune de tauris vaccisque dicemus.

('Now that we have given enough instruction about oxen, it will be proper to deal next with bulls and cows.' Col. 6.20) ${ }^{3}$

(2) Nunc quoniam plerosque nostrum civilis ambitio saepe evocat ac saepius detinet evocatos, sequitur, ut suburbanum praedium commodissimum esse putem, quo vel occupato cotidianus excursus facile post negotia fori contingat.

('But as things are, since political ambition often calls most of us away, and even more often keeps us away when called, I consequently rate it as most advantageous to have an estate near town, which even the busy man may easily visit every day after his business in the forum is done.' Col. 1.1.19)

(3) Itaque nusquam experimentorum varietas omittenda est, longeque etiam in pingui solo magis audendum, quoniam nec laborem nec sumptum frustratur effectus.

('Accordingly, there should be no neglect, anywhere, of experimentation in many forms; and far greater daring should be shown on rich soil, because the return will not render the toil and expense a total loss.' Col. 1.4.5)

(4) ... quod in re rustica nullo minus opere fatigatur prolixior, quia in arando stivae pene rectus innititur.

2 The first quoniam clause in answer to quid ita? on the BTL cd-rom is in Fortunatianus (Ars Rhetorica 1.7).

${ }^{3}$ The translations are taken from the various Loeb editions. Those of Tertullian are from the Corpus scriptorum latinorum website (http://www.forumromanum.org/ literature). 
( $\ldots$ because in the work of the farm there is no task less tiring to a tall man; for in ploughing he stands almost erect and rests his weight on the plough-handle.' Col. 1.9.3)

A question that was left open in the publication on Columella is to what extent these uses correspond with the uses of quia and quoniam in Classical Latin and, more generally, whether a development can be noted of quoniam towards the use of quia and quod. That is the subject of the present article. To that end I have examined 25 instances of quia and quoniam in portions of texts by Cicero (N. D.), Seneca (dial.), and Tertullian (Nat. + Apol., Test. and Praescr.-to arrive at 25 instances of quoniam). I also examined all the instances (29) of quod in Cicero N. D. and had a look at quod in Tertullian Nat., because they were easy to locate. ${ }^{4}$ These works have in common that they deal with an abstract subject matter. They differ from Columella on the one hand in that they are less complete and systematic in the treatment of their subject matter and are not intended as practical manuals. On the other hand they show more personal involvement. Cicero's $N . D$. is a dialogue. We should therefore not expect exactly the same uses as mentioned for Columella and certainly not the same mix of uses.

\section{A Few Statistical Observations}

First a few statistical data. In the first place, quoniam is the most frequent causal subordinator in Columella, as it is in the rhetorical manuals Rhetorica ad Herennium and Cicero's De Inventione. On the other hand quoniam is remarkably infrequent in my samples of Seneca and Tertullian. In the N. D. quia is more frequent than quod, although quod is usually said to be the most common of the two in Classical Latin (in Early Latin quia is by far the most frequent). It is not uncommon to find cataphoric (rarely anaphoric) adverbial expressions in the main clause corresponding with the subordinators quia and especially quod in all periods of Latin (see below). They are particularly frequent in Tertullian (14 and 13 instances, respectively), which may have to do with the widening use of these subordinators (see below).

\footnotetext{
4 Taken from Merguet's Lexikon (a few cases eliminated). The data on quia and quod and the use of cataphoric expressions like ideo 'therefore' with them in Tertullian are taken from Borleffs' edition (1929).
} 
As for the relative position of the causal clauses, the overall figures can be read below. The relative order of causal and main clauses corresponds with the distribution of information over these clauses: salient information usually follows. Remarkable is the order of quod clauses, shown here only for Cicero. Apart from the general explanation just given, its following the main clause may also have to do with the fact that quod is a highly polysemic word, and therefore not the most likely word to start a sentence with. Cicero shows more flexibility for quia than the other authors. He has quoniam clauses predominantly before the main clause, followed in this respect by Tertullian only. In Columella and Seneca quia and quoniam seem exchangeable as far as word order is concerned. In the M q M instances the causal clause is related to the core of the main clause, which either precedes or follows. Semantically they are not different from the $\mathrm{q} M$ and $\mathrm{M}$ q instances. Note that in the first table all instances that occur in the works cited are recorded (many more than the circa 25 instances in the actual samples that I use for studying their function).

Frequency of quia, quoniam, quod (for quod the information is incomplete)

Cicero Seneca Tertullian Columella

N. D. dial. 1-9 Nat.

$\begin{array}{lllll}\text { quia } & 44 & 99 & 43 & 113 \\ \text { quoniam } & 32 & 25 & 13 & 212 \\ \text { quod } & 28 & ? & 22 & ?\end{array}$

Order of q-clause and $\mathrm{M}$ (ain)-clause in the samples

\begin{tabular}{llllllllll} 
& \multicolumn{2}{l}{ Cicero } & \multicolumn{3}{c}{ Seneca } & \multicolumn{2}{c}{ Tertullian } & \multicolumn{2}{c}{ Columella } \\
& qi $^{5}$ & qn & qd & qi & qn & qi & qn & qi & qn \\
q M & 10 & 18 & 2 & 5 & 6 & 2 & 12 & - & 1 \\
M q M & 2 & 2 & 1 & - & 1 & 1 & - & 2 & 6 \\
M q & 11 & 5 & 26 & 24 & 19 & 21 & 10 & 24 & 18
\end{tabular}

5 'qi' = quid, 'qn' = quoniam, 'qd' = quod. The totals are not always 25 , due to the fact that certain instances cannot simply be described as subordinate clause and main clause. In other sentences there are more instances. 


\section{Illocutionary Disjunct Clauses with quoniam}

Let's now turn to semantics. In ex. (1) above the quoniam clause justifies the way Columella organizes his text. This is a common usage in monologal treatises, in prose, as in Varro's de Lingua Latina and Cicero's de Inventione, but also in didactic poetry, as in Lucretius (quoniam docui 'since I have taught' -1.265 and elsewhere). An interesting example from Seneca is (5). It has two quoniam clauses, the first (typically preceding the main clause) of the type just illustrated, the second (following the main clause, as usual in Seneca) being an example of logical inference, discussed in $\$ 4$. The function of the first quoniam clause resembles that of pseudofinal clauses (ut liberaliter agam). Related is the the use of quoniam clauses to justify the speaker or writer's decision to deal with a certain topic by referring to the wish or behaviour of his addressee(s), as for example quoniam ita voluistis 'as such was your wish' in Cic. de Orat. 1.203. I found no precise parallels in the passages examined. A third type, absent in the passage taken from Columella, can be illustrated with example (6) from Seneca. It shows a quoniam clause that justifies the choice of a specific wording.

(5) Quoniam liberaliter agere coepi, potest beatus dici qui nec cupit nec timet beneficio rationis, quoniam et saxa timore et tristitia carent nec minus pecudes.

('Seeing that I am employing some freedom in treating my subject, I may say that the happy man is one who is free from both fear and desire because of the gift of reason; since even rocks are free from fear and sorrow, and no less are the beasts of the field ...' Sen. dial. 7.5.1)

(6) Amicitiam dico? Immo etiam necessitudo et similitudo, quoniam quidem bonus tempore tantum a deo differt ...

('Friendship, do I say? Nay, rather there is a tie of relationship and a likeness, since, in truth, a good man differs from God in the element of time only; ...' Sen. dial. 1.1.5)

What these three types of quoniam clauses have in common is that they serve to position the content of the main clause in the communicative situation of the author and his audience by commenting on the wording of the text, its relevance to its context, and the relationship between the author and his audience. In more technical terms, they are illocutionary disjuncts: they refer to the speech act. There are no instances of quia clauses used in this way in the samples examined, nor have I found instances elsewhere in these works.

In the $N$. D. passage I found two instances of illocutionary quoniam disjuncts $(2.23,3.20)$. Among the instances of quoniam in the Seneca 
sample I count six as illocutionary $(1.1 .1,1.1 .5,1.10 .1,4.18 .1,7.5 .1$, 9.9.5). In the Tertullian sample I find seven instances (Nat. 2.1.4, 2.14.1, Apol. 4.3, 9.6, 11.1, 21.1-2, 25.2).

\section{Attitudinal Disjunct Clauses with quoniam}

Examples (2) and (3) are much more common than ex. (1). In ex. (2) the quoniam clause contains an observation which supports Columella's quality judgment (and indirectly justifies the advice the reader is expected to read in this quality statement). In ex (3) the quoniam clause refers to a state of affairs that justifies the action or the behaviour recommended by Columella. This usage is not found in this form as frequently in the $N$. D. and the other texts, probably because they are not intended as practical manuals and have less of an instructional character. On a more abstract level, however, many of Cicero's quoniam clauses are comparable. The quoniam clause most often contains an observation, generally verifiable and undisputed, which justifies the logical inference in the main clause. Typical examples of this use of quoniam are (7) and (8). Note in ex. (7) the presence of necesse 'of necessity' in the main clause.

(7) Necesse est, quoniam pallet, aegrotasse.

('Since he is pale, he must have been sick.' Rhet. Her. 2.39)

(8) Quoniam peperit, cum viro concubuit.

('Since she has borne a child, she has lain with a man.' Cic. Inv. 1.74)

What unifies these uses of quoniam clauses is that they contain information to support the correctness of the content of the main clause, whether it is an assertion or an advice (or, as we will see, an intention). In this respect quoniam clauses resemble attitudinal disjuncts, through which 'the speaker ... takes personal responsibility for the content of the proposition' (Dik 1997: 242; Pinkster 2004: 192).

In the $N$. D. passage most instances of quoniam are of the type logical inference, twenty in total, three other are justifications of a question or a piece of advice $(1.87,2.7,2.168)$. The main clause often contains an explicit expression (lexical or morphological) of the need to draw a certain conclusion (see ex. 10), but this is not necessary (ex. 9). ${ }^{6}$ A disturbing

\footnotetext{
${ }^{6}$ For the range of expressions of obligation or permission in this type of texts see Gibson (1997: 72-73 [on prose]; 80-81 [on verse]).
} 
sequence of quoniam and quia clauses can be found in (10). The speaker is Cotta, who in this passage is attacking Velleius, more or less paraphrasing his words. Velleius' actual words are given in (11). It is interesting to note that Cotta, in his usual vehement style, replaces Velleius' first si (a hypothetical conclusion) by quoniam (a logical inference based on a commonly agreed state of affairs), although presenting it as a quote (ut ais), and his second si by quia. Rackham translates both quoniam and quia with 'because' and this is at first sight attractive given the parallelism of expression. However, I would like to see a difference between the two, with quia marking the unavoidable natural outcome of a state of affairs that is taken for granted. In this interpretation Cotta distorts Velleius' words even more in his second paraphrase. A confirmation for this interpretation may be found in the fact that in this sample Cicero has no other instances of quia in logical inferences.

(9) Terra enim profecto, quoniam mundi pars est, pars est etiam dei.

('Now clearly the earth, being part of the world, is also a part of god.' Cic. N. D. 1.24)

(10) Confugis ad aequilibritatem ... et ais, quoniam sit natura mortalis, inmortalem etiam esse oportere. Isto modo, quoniam homines mortales sunt, $\operatorname{sint}^{7}$ aliqui inmortales, et quoniam nascuntur in terra, nascantur in aqua. 'Et quia sunt quae interimant, sint quae conservent'. Sint sane, sed ea conservent quae sunt. Deos istos esse non sentio.

('You take refuge in the principle of 'equilibrium', and you say that because there is mortal substance there must also be immortal substance. On that showing, because there are mortal men, there are also some that are immortal, and because there are men born on the land, there are men born in the water. 'And because there are forces of destruction, there are also forces of preservation. Suppose there were, they would only preserve things that already exist; but I am not aware that your gods exist.' Cic. N. D. 1.109)

(11) Ex hac igitur illud efficitur, si mortalium tanta multitudo sit, esse inmortalium non minorem, et si quae interimant innumerabilia sint, etiam ea quae conservent infinita esse debere.

('From this principle it follows that if the whole number of mortals be so many, there must exist no less a number of immortals, and if the causes of destruction are beyond count, the causes of conservation are also are bound to be infinite. Cic. N. D. 1.50).

\footnotetext{
7 Rackham, in his Loeb edition, reads indicative forms sunt and nascuntur.
} 
The non-illocutionary instances of quoniam clauses in Seneca's sample are either justifications (seven) or logical inferences (thirteen). ${ }^{8}$ An interesting combination of a quoniam clause that serves as a justification of Seneca's behaviour with two quia clauses that are contrasted with each other is (12).

(12) Hoc Stoicis quoque placere ostendam, non quia mihi legem dixerim nihil contra dictum Zenonis Chrysippive committere, sed quia res ipsa patitur me ire in illorum sententiam, quoniam si quis semper unius sequitur, non in curia sed in factione est.

('I shall show, too, that the Stoics also accept this doctrine, not because I have made it my rule to set up nothing contrary to the teaching of Zeno or Chrysippus, but because the matter itself suffers me to adopt their opinion; for if a man always follows the opinion of one person, his place is not in the senate, but in a faction.' Sen. dial. 8.3.1)

In Tertullian, too, instances of attitudinal use of quoniam are present. I count five quoniam clauses that serve as a justification for desired or intended behaviour (Nat. 1.10.31, 2.3.2, 2.9.2, 2.9.11, Apol. 28.1) and three logical inferences (Nat. 1.8.12, Apol. 30.5, Test. 1.7). Examples are (13) and (14), respectively. Notice in (14) the presence of the particle quidem in the quoniam clause, underlining the cohesion between thisparenthesis-like-clause and its preceding main clause. ${ }^{9}$ Tertullian uses this combination more often, for example in (20), as does Augustine later on. It was also common in Cicero, Columella, and Seneca (see ex. 6). Quia quidem does not exist.

(13) Sed quoniam omnis superstitio non iam philosophorum nec poetarum nec populorum, a quibus tradita est, sed dominantium Romanorum, a quibus occupata est, a quibus auctoritatem sibi extruxit, alia iam nobis ineunda est humani erroris latitudo, immo silva caedenda ...

('Since, however, it is no longer to the philosophers, nor the poets, nor the nations that we owe the substitution of all (heathen worship for the true religion) although they transmitted the superstition, but to the dominant Romans, who received the tradition and gave it wide authority, another phase of the widespread error of man must now be encountered by us; nay,

${ }^{8}$ As justifications I count: Sen. dial. 4.24.1, 6.12.3, 7.1.2, 7.25.1, 8.3.1, 9.8.9, 9.10.5; as logical inferences: $1.4 .4,2.8 .2,3.8 .1,4.6 .1,4.11 .4,4.12 .2,5.5 .5,6.17 .7,7.5 .1,7.5 .2,7.6 .1$, 7.24.5, 8.5.8.

${ }^{9}$ For this function of quidem see Kroon (2005; 2009). See also Rosén (2009: 424429). 
another forest must be felled by our axe, which has obscured the childhood of the degenerate worship with germs of superstitions gathered from all quarters.' Tert. Nat. 2.9.2-transl. Holmes)

(14) Ubi autem Graeci? Vel si in Romanorum superstitionibus censentur, quoniam quidem etiam deos Graeciae Roma sollicitavit, ubi saltem Aegyptii, et ipsi, quod sciam, privati curiosaeque religionis?

('Where, then, are the Greeks? Or if they are reckoned amongst the Romans in regard to their superstition (since it was from Greece that Rome borrowed even her gods), where at least are the Egyptians, since these have, so far as I know, a mysterious religion peculiar to themselves?' Tert. Nat. 1.8.12-transl. Holmes)

\section{5. 'Deviant' Uses of quoniam}

The attentive reader will have noticed that for Cicero and Seneca the numbers given for illocutionary and attitudinal instances of quoniam add up to the ca. twenty five instances that have been selected for analysis. In the case of Tertullian ca. ten instances are lacking. In three of these a definitive analysis is impossible because the text is unclear or disputed (Nat. 2.11.4-5, 2.12.37, Apol. 6.2). No less than four instances have properties that are typical of quia clauses. There are two instances of a corresponding causal adjunct in the main clause, one with idcirco 'therefore' (Nat. 1.9.10), another slightly more complex (15). One is in answer to a question unde 'why' (Nat. 2.3.11), more parallels of which are found outside the corpus (16). The most conspicuous instance is (17), where the quoniam clause forms part of an adversative coordinate construction with non ... sed. It is very uncommon for disjuncts to be denied, so one does not expect non quoniam, whereas non quia is relatively common (see ex. 17). My sample does indeed not contain instances of non quoniam. There is, however, (only) one instance elsewhere in Tertullian of non quoniam (18) (there are furthermore five instances with non or nec in Augustine).

(15) ... cum $o b$ hoc sit casticandus propter quod ... Dehinc quoniam nihil proficiat congressio scripturarum, nisi plane ut aut stomachi quis ineat eversionem aut cerebri.

('... seeing that he ought to be corrected, for the very reason that he is not to be disputed with; and in the next place, because a controversy over the Scriptures can, clearly, produce no other effect than help to upset either the stomach or the brain. Tert. Praescr. 16.2-transl. Holmes) 
(16) Cur ita? Quoniam subsequens sermo prophetae exprobrat eis dicens: ...

('Why so? Because the subsequent discourse of the prophet reproaches them, saying ...' Tert. Iud. 3.5-transl. Therwell)

(17) In pugna pugilum et gladiatorum plerumque non quia fortis est vincit quis aut quia non potest vinci, sed quoniam ille qui victus est nullis viribus fuit.

('In a combat of boxers and gladiators, generally speaking, it is not because a man is strong that he gains the victory, or loses it because he is not strong, but because he who is vanquished was a man of no strength.' Tert. Praescr. 2.7-transl. Holmes)

(18) Plane. Quoniam, inquit, in potestate erat sermo eius, non quoniam adversus legem et prophetas docebat.

('Of course they were; for, he says (St. Luke), ${ }^{10}$ His word was with powernot because He taught in opposition to the law and the prophets.' Tert. Marc. 4.7.7-transl. Holmes)

These instances show that quoniam, while maintaining its classical illocutionary and attitudinal disjunct functions is also used as an adjunct, in the way quia is. There are also instances without such formal characteristics which can best or only be interpreted as equivalent to quia (in my sample Nat. 1.12.7, I think).

There are other 'deviant' uses of quoniam, some of which it shares with equally 'deviant' uses of quia. The best known is its-rare-use in argument clauses with verba sentiendi (video, ostendo)-no instances in the sample. Related to this may be the use of quoniam (once) and quia (twice) in a difficult passage in our sample (19). Perhaps we should explain this use of quia and quoniam by referring to expressions like parum est quod 'it is not enough that', where the quod clause is subject in the sentence (although the Thesaurus linguae Latinae (s.v. parum, $573.55 \mathrm{ff}$.) has no examples of quia). Another use of quoniam that is better known from quia is exemplified in (20). Quoniam quidem mortalis is brachylogically joined to minima. Compare (21) for quia (also Nat. 1.4.7, 1.8.8, 2.1.14). ${ }^{11}$

(19) Parum scilicet humanis visceribus inhiatis, quia vivos et puberes devoratis? Parum humanum sanguinem lambitis, quoniam futurum sanguinem elicitis? Parum infante vescimini, quia infantem totum praecocum perhauritis?

${ }^{10}$ Et stupebant in doctrina eius, quia (SIC!) in potestate erat sermo ipsius. (Vulg. Luc. 4.32).

${ }^{11}$ For the use of causal subordinators with participles in Tertullian see Hoppe (1903: $59)$. 
('I wonder whether it be a small matter to you to pant for human entrails, because you devour full-grown men alive? Is it, forsooth, only a trifle to lick up human blood, when you draw out the blood which was destined to live? Is it a light thing in your view to feed on an infant, when you consume one wholly before it is come to the birth?' Tert. Nat. 1.15.8-transl. Holmes)

(20) Consiste in medio, anima; seu divina et aeterna res es secundum plures philosophos, eo magis non mentieris, seu minime divina quoniam quidem mortalis, ut Epicuro soli videtur, eo magis mentiri non debebis ...

('Stand forth, O soul, whether thou art a divine and eternal substance, as most philosophers believe if it be so, thou wilt be the less likely to lie,- - or whether thou art the very opposite of divine, because indeed a mortal thing, as Epicurus alone thinks-in that case there will be the less temptation for thee to speak falsely in this case: ...' Tert. Test. 1.5-transl. Theswell)

(21) Denique apud philosophos 〈incerta $\rangle$, quia varia; apud poetas omnia indigna, quia turpia; apud populos passiva omnia, quia voluntaria.

('Now all things with the philosophers are uncertain, because of their variation with the poets all is worthless, because immoral; with the nations all is irregular and confused, because dependent on their mere choice.' Tert. Nat. 2.1.13-transl. Holmes)

\section{Adjunct Clauses with quia}

Most properties of quia clauses have been mentioned in passing above. Below are just two more typical instances to illustrate quia adjuncts. (22) superficially resembles the illocutionary example (1) above. However, the quia clause in (22) does not contain manifestly shared knowledge of the discussants. A similar motivation for not discussing a topic can be seen in Seneca dial. 3.4.2 and Tertullian Nat. 1.17.5. (23) is one of several etymological derivations of proper names.

(22) Sed quia commune hoc est argumentum aliorum etiam philosophorum, omittam hoc tempore.

('Still, as it is a line of reaoning that is followed by other philosophers as well, I will pass it over for the present.' Cic. N. D. 1.64)

(23) Diana dicta quia noctu quasi diem efficeret.

('She was called Diana because she made a sort of day in the night-time.' Cic. N. D. 2.69)

It is interesting to examine a few quia clauses in the Seneca sample where the Loeb translation has 'since', the common translation for quoniam. In 
(22) the quia clause looks like a generally accepted truth that might serve as support for the logical conclusion in the main clause, but since it is explicitly formulated as a debatable issue quia may be more appropriate than quoniam. Two other seemingly logical inference cases, where the content of the quia clause is perhaps not as self-evident as it seems, are dial. 2.5.5 and 3.6.5. In (23) the quia clause seems at first sight to contain the justification for the order 'isto modo dic + accusative and infinitive' and that may be the reason for the translation 'since'. I believe that the quia clause gives the reason for the content of the accusative and infinitive clause, just as the preceding utilis ... ira est quia pugnaciores facit, translated as 'anger is more profitable ... because it makes men more warlike'. I see no reason to assume on the basis of these cases that in Seneca quia is extending its semantic field in the direction of quoniam. I would rather assume that that there is some choice in certain causal configurations.

(22) Ideo fortiter omne patiendum est, quia non, ut putamus, incidunt cuncta sed veniunt.

('Therefore everything should be endured with fortitude, since things do not, as we suppose, simply happen - they all come.' Sen. dial. 1.5.7)

(23) Isto modo dic et phrenesin atque insaniam viribus necessariam, quia saepe validiores furor reddit.

('By the same reasoning you must also say that lunacy and madness are essential to strength, since frenzy often makes men more powerful.' Sen. dial. 3.13.3)

A number of 'deviant' instances of quia in Tertullian have been discussed in $\$ 4$. Among the remaining instances most are straightforward quia adjuncts. Three instances merit closer attention. In Nat. 1.7.7 the text is uncertain. ${ }^{12}$ The quia clause probably explains why Fame is such a bad creature, but the sense remains unclear to me. In Nat. 1.10.8 the quia clause probably explains why a crowd of populares had gathered, but here, too, the sense remains unclear. In the third instance (24) Holmes translates quia with 'since'. The information of the quia clause is in strong contrast (non) with the preceding exclamative sentence (compare Nat. 1.9.2 quia non miror-the only other instance of a preceding quia clause in the Tertullian sample) so it is unlikely that in Classical Latin quoniam would have been more appropriate. In view of the uncertainties

12 Thesaurus linguae Latinae, s.v. prodigium, $1609.23 \mathrm{ff}$. reads quale prodigium. 
concerning these three instances I conclude that there are no clear signs in Tertullian of a development of quia in the direction of quoniam.

(24) Quia non odistis quod estis, date dextras potius, compingite oscula ...

('Since you do not (of course) hate what you yourselves are, give us rather your right hands in fellowship, unite your salutations, mingle your embraces ...' Tert. Nat. 1.20.2)

\section{A Few Comments on quod}

Quod is usually regarded as synonymous with quia, although there are certain differences in frequency and distribution (it does not occur in answer to cur 'why' questions-see Pinkster 2009: 313). Most quod clauses in the Cic. N. D. sample are indeed clear adjuncts. They are, for instance, used in etymological derivations of names (N. D. 2.64) and coordinated with other adjuncts (25). There are a few instances where Rackham translates with 'since', one of which is given in (26). The argumentation of the passage is complex, with itaque indicating a logical inference between the two main clauses, the second of which needs argumentation as well. Quoniam looks like a good alternative for quod, but perhaps talia is too context dependent. In (27), finally, quoniam seems not excluded instead of quod, but the latter presents nihil fore in nostra postestate as the inevitable result of the regularity of the movements of the atoms.

(25) Idque evenit non temere nec casu, sed quod et praesentes saepe di vim suam declarant ...

('Nor is this unaccountable or accidental; it is the result, firstly, of the fact that the gods often manifest their power in bodily presence.' Cic. N. D. 2.6)

(26) Quod si ita est, vere exposita illa sententia est ab Epicuro, quod beatum aeternumque sit id nec habere ipsum negotii quicquam nec exhibere alteri, itaque neque ira neque gratia teneri, quod quae talia essent inbecilla essent omnia.

('If this is so, the famous maxim of Epicurus truthfully enunciates that "that which is blessed and eternal can neither know trouble itself nor cause trouble to another, and accordingly cannot feel either anger or favour, since all such things belong only to the weak."' Cic. N. D. 1.45)

(27) Velut Epicurus cum videret, si atomi ferrentur in locum inferiorem suopte pondere, nihil fore in nostra potestate, quod esset earum motus certus et necessarius, invenit ... 
('For instance, Epicurus saw that if the atoms travelled downwards by their own weight, we should have no freedom of the will, since the motions of the atoms would be determined by necessity. He therefore invented ...' Cic. N. D. 1.69)

\section{Conclusion}

In my samples of Cicero, Seneca, and Tertullian quia and quoniam are used in a way similar to what I observed for Columella in Pinkster (2009): quia clauses are adjuncts, quoniam clauses disjuncts. There is no sign (yet) that they became synonymous after the Classical period. I did find a number of instances of quoniam in Tertullian that are exchangeable with quia, which suggests that the use of quoniam widened. I also found in this author a number of instances of both quia and quoniam that deviate from Classical Latin altogether and are part of the more general widening or less accurate use of subordinators in Late Latin. ${ }^{13}$

\section{References}

Bolkestein, Alide Machtelt. 1991. Causally related predications and the choice between parataxis and hypotaxis. In New Studies in Latin Linguistics, ed. Robert Coleman, pp. 427-452. Amsterdam: Benjamins.

Borleffs, Jan Willem Philippus. 1929. Quinti Septimi Florentis Tertulliani Ad nationes libri duo. Leiden: Brill.

Fugier, Huguette. 1989. Quod, quia, quoniam et leurs effets textuels chez Cicéron. In Subordination and Other Topics in Latin, ed. Gualtiero Calboli, pp. 91-119. Amsterdam: Benjamins.

Gibson, Roy. 1997. Didactic poetry as 'popular' form: a study of imperatival expressions in Latin didactic verse and prose. In Form and Content in Didactic Poetry, ed. Catherine Atherton, pp. 67-98. (Nottingham Classical Literature Studies, vol. 5) Bari: Levante Editore.

Hoppe, Heinrich. 1903. Syntax und Stil des Tertullian. Leipzig: Teubner.

Herman, József. 1963. La formation du système roman des conjonctions de subordination. Berlin: Akademie Verlag.

Kroon, Caroline H.M. 2005. The relationship between grammar and discourse: evidence from the Latin particle quidem. In Latina Lingua!, ed. Gualtiero Calboli, pp. 577-590. Rome: Herder.

- 2009. Latin Linguistics between Grammar and Discourse. Units of Analysis, Levels of Analysis. In Pragmatische Kategorien. Form, Funktion und Diachronie, ed. Elisabeth Rieken and Paul Widmer, pp. 143-158. Wiesbaden: Reichert.

${ }^{13}$ For these developments see Herman (1963). 
Mellet, Sylvie. 1994. Eléments pour une étude de la synonymie syntaxique: l'exemple des conjonctions de cause. In Les problèmes de la synonymie en Latin, ed. Claude Moussy, pp. 203-221. Paris: Presses de l'Université de ParisSorbonne.

-1995. Quando, quia, quod, quoniam: analyse énonciative et syntaxique des conjonctions de cause en latin. In $D e U s u$, ed. Dominique Longrée, pp. 211228. Leuven: Peeters.

Pinkster, Harm. 1990. Latin Syntax and Semantics. London: Routledge (also on: http://cybergreek.uchicago.edu/lss/, with additions and corrections).

- 2004. Attitudinal and illocutionary satellites in Latin. In Words in their Places. A Festschrift for J. Lachlan Mackenzie, ed. Henk Aertsen et al., pp. 191198. Amsterdam: Vrije Universiteit (also on: www.harmpinkster.nl).

. 2009. De Latijnse voegwoorden quia en quoniam (en Nederlands aangezien). In Fons verborum. Feestbundel Fons Moerdijk, ed. Egbert Beyk et al., pp. 313-320. Leiden: INL (also on: www.harmpinkster.nl, with additional appendices).

Rosén, Hannah. 2009. Coherence, sentence modification, and sentence-part modification-the contribution of particles. In New Perspectives on Latin Syntax. I. The Sentence, ed. Philip Baldi and Pierluigi Cuzzolin, pp. 317-441. Berlin: Mouton de Gruyter.

Szantyr, Anton. 1965. Lateinische Syntax und Stilistik. Munich: Beck. 